\title{
Historical and Symbolic Aspects of Linguistic Representation of the World
}

\author{
Margarita Ganyushina \\ Russian State Social University \\ Correspondence concerning this article should be addressed to Margarita Ganyushina, Russian State \\ Social University, building 5, 4 Wilhelm Pieck Str., Moscow, Russian Federation, 129226. \\ E-mail: margarita1962@list.ru
}

\begin{abstract}
The article is an attempt to offer a theoretical understanding of the notion of a "Linguistic world-image" (LWI) within symbolic contexts as represented in the current literature, define the symbol's features, its influence on LWI in historic perspective, and investigate its functioning within idioms or metaphors. We have undertaken the review of previous LWI investigations and, as the methodological basis of our research, we have used ethno-semantic and linguisticphilosophical approaches to language; specifically, the method of multiple etymology, introduced by V. N. Toporov and developed by M.M. Makovsky, which permitted us to identify the correlation of LWI with linguistic signs as a carrier of symbolic meaning. It should be noted that studying symbolic language properties and linguistic signs within the linguistic world-image, which were not taken into account before, is conductive to a more profound comprehension of the correlation between language, culture, and mutual understanding index in the intercultural communication process. The LWI concept is considered as a subjectiveobjective dynamic multilevel construct, which presents its primary features through a lexicalsemantic language system within a world and national culture formed as a result of the reflection of sensorial perception, facts, understanding and estimation of the objective phenomena in national linguistic consciousness, in the experience of correlation of language concepts, images and symbols throughout the cultural historical development of the language. Therefore, two approaches to studying LWI are evident - cognitive and cultural-philosophical - which are not so much conflicting as mutually reinforcing.
\end{abstract}

Keywords: symbolic language properties, linguistic sign, linguistic world-image, linguistic thinking, linguistic consciousness, inner form

The study of symbolic language properties and linguistic signs within LWI is of utmost importance in the active interaction of cultures and peoples. It leads to a more profound comprehension of the correlation between language, culture, and the level of understanding during the intercultural communication process. For this reason, a theoretical understanding of the linguistic world-image concept in symbolic contexts is pressing and necessary. The review of previous LWI research has revealed that it was mostly reduced to the analysis of metaphor combinations of words having abstract semantics, which singled out perceptible sensory images (Arutyunova, 1976; Apresyan, 1995; Teliya, 1996; Lakoff \& Johnson, 1987; Vezhbitskaya, 1996; Zaliznyak, 2005; Kornilov, 2002; Radchenko, 2002). It did not take into account the symbolic aspect of LWI, which may open up new avenues of research. Any national language is known to reflect not only scientific knowledge about the world but also includes things that do not correlate with objective reality, such as metaphors, idioms, and mythical images. This leads us to conclude that symbols and mythological images function in idioms and metaphors because the early culture fixed in a language is held to be a mythological one. It did not disappear completely but continues to live in metaphors, idioms, and proverbs. In that context, the symbol can be considered as the element of cultural information that is used in the speech and linguistic codes of different cultural representations. As a result, we propose one more algorithm of LWI study taking into account its symbolic content. The premise is 
that LWI research, from the point of view of symbols functioning in a language, allows us to understand a nation's world perception and evolution; it enables us to explain why the same ideas are expressed in distinct ways in different languages.

\section{Materials and Methods}

To clarify the challenges faced in studying LWI and deduce its research technique, we have summarized previous theories on linguistic world-image and the correlation of sign and symbol functioning in metaphors and idioms, pointing out flaws or demonstrating the advantage of one theory over another. This analysis has enabled us to suggest the algorithm of symbol content research functioning in metaphors and idioms.

The notion "linguistic world-image" goes back directly to ideas of W. von Humboldt (1821), L. Wittgenstein (1918), L. Weisgerber (1929), E. Sapir and B. Whorf (1954). W. von Humboldt's study (1767 - 1835) on language was the foundation for the notion of the linguistic world-image. The cornerstone of his study was the notion of "objective reality", without which it was impossible to create the relevant concept about the correlation between language, man and the world itself. His doctrine about a linguistic inner form formed the basis of the concept of LWI.

Von Humboldt connected "the national spirit" with national creative activity of consciousness to create "complex ideas of not only objective reality, but also national emotions, feelings, sensations and perceptions about existence", creatively meaningful by a collective" subject of thought". "Language is closely intertwined with the spiritual advance of mankind and accompanies it at each phase of its local progress or regress reflecting every stage of culture" (Humboldt, 2000, p. 48).

In the early twentieth century, under the influence of Ferdinand de Saussure's ideas, the LWI description began to be realized not only in terms of philosophic and inter-linguistic descriptivism, but also as a sociological approach: "Finally WI had acquired the environment in which it forms and exists, i.e., 'the speech community" (Radchenko, 2002, p. 141). Until that time, this problem had only been apparent but not considered. Firstly, German scholars such as Tennis, Durkheim, Firkandt, Maine, etc. made an outstanding contribution to give a social-linguistic direction to the world image conceptualization. In Russia, the problem of describing WI and the speech community was raised during the ethnic psychology formation and its research is associated with the name of G. G. Shpet $(1879-1940)$.

Austrian philosopher and logician Ludwig Wittgenstein $(1889$ - 1951) saw the WI notion as a metaphor and emphasized its identity with the mental concept of "the image of the world" and introduced a new approach to language analysis in general and subsequently to the study of LWI to consider the word meaning in its usage. But to perceive the world through language is a "misconception" (Fefilov, 2004, p. 44).

From the perspective of modern linguistic science, thought and language are not identical, hence the notion is a unit of thinking and the meaning is a linguistic unit. Accordingly, the notion is expressed while meaning is inserted in the sign, correlating with the object and actively interacting with the mental concept. Therefore, we cannot say that the "picture" created by language is captured by everybody. Language does not draw anything, it is just "a way of expressing the objective world reflected in the conceptual mind".

Many modern Russian scholars such as Yu. D. Apresyan (1995), Yu. S. Stepanov (2001), N. D. Arutyunova (1976), T. V. Bulygina and D. N. Shmelyov (2000), E. S. Kubryakova (1993) devoted their work to LWI problem. O. A. Kornilov (2003), V. N. Thalia (1996), R. H. Khayrullina et al. (2008) engaged in studying word-formation and phraseological resources of LWI; O. A. Radchenko (2002) studies dialect pictures of the world, M. M. Makovsky (2005), T. V. Toporova (1999) are engaged in mythological decoding of world images in Indo-European languages. O. A. Radchenko (2002) devoted his work to the history of the idio-ethnic direction in language philosophy. A. Vezhbitska's works (1997 et al.) show the necessity of overcoming purely linguistic borders in research and the use of national psychology, national mentality and national cultural data. The correlation between language and thinking is actively investigated in psycholinguistics. A. N. Leontyev's (1983), E. F. Tarasov's (2000), E. V. Sidorov's (2011) work convincingly proves the interactive character of verbal communication. According to S. N. Kurbakova (2013), "being engaged in interaction with other people to achieve some aims, an addresser has to effectively control the recipient's activity during the communication. The person acts in a certain situation (place), and in a broad sense, space, at a certain time or period of time". S. N. Kurbakova believes that "by studying verbal orientation of speech according to the coordinates of person, place and time of activity we get an opportunity to describe the essential parameters of objective reality which are in human consciousness" (Kurbakova, 2013, p. 97).

Having analyzed some basic theoretical directions, we can conclude the following. Consciousness, being a receptive, accumulative and estimated component, provides perception, logical judgment and information assessment. In our consciousness there is a processing of evident feelings, a fixing of their cogitative images and the formation of a conceptual worldview. As consciousness correlates language and objective reality, it takes an intermediate position between language and the objective world. As a result of a world objectification, 
consciousness presents not only the idea about the thing itself and its initial properties independent of human life, but also reflects its socially significant properties acquired subsequently through personal and public experience. Thereupon, it is possible to say that because of geographical, cultural, historical, social and other distinctions, objective reality is reflected in different nations' consciousness unequally, according to national beliefs as human consciousness is formed to a certain extent under the impact of national culture.

Therefore, we can speak about the notion "national consciousness" which forms the socalled "national linguistic world-image". A logicalconceptual component of consciousness segments an infinite information stream and turns it into a set of information bundles (O. A. Kornilov defines this as "informema"), which become concepts of a national linguistic consciousness (Kornilov, 2003, p. 147). Cogitative images and concepts are verbalized through a person's desires and linguistic reasoning as a dynamic component to transform and explain objective reality. Trying to explain events and phenomena of objectivity, the human consciousness draws from a whole number of symbols available to the system of traditional national beliefs. During the early stages of national development, current events and processes of the universe were understood through mythological justification, with the system of images and symbols as the only thing available for that period.

Thanks to the creative activity of linguistic thinking and its associative orientation, abstract notions and physical facts are actualized by cogitative images and real-life objects, their signs and the relations already available in memory, subjective and estimated orientation. The emotional assessment of an image is the cornerstone of an associative correlation with a sign. Thus, in the course of reflection the real image at the consciousness level can have both significant and connotative conceptual content. Metaphorical constructions, which are the code and the meta-code of our thoughts, appear. The correlation of language concepts, images and symbols caused by the language experience and national features of native speakers helps make the so called "national linguistic world image" (NLWI).

It should be noted that a mutual understanding between people of different nationalities occurs because of the uniform logical-conceptual base of mental universals and a substantive universal code (according to N. I. Zhinkin's terminology), which make thinking independent of national languages and cultures (Kornilov, 2003, p. 121). Distinction is formed as a result of development, concretization and specification of a universal logical conceptual basis by each ethnos. Everything that is beyond the substantive universal code, on the periphery of a logical-conceptual framework of the world order, is nationally determined and specific. Idioms and metaphors are on the periphery and they are the components of NLWI. Idioms can carry out the function of cultural-national world-vision standards. Early mythological culture was fixed in a language, primarily in idioms and metaphors.

Thus, "symbol", "sign", "image" and "metaphor" are fundamental concepts to deduce the algorithm of an ethnic linguistic representation. The LWI notion is based on the close correlation of a linguistic sign as the carrier of symbolic value, images and characters of heathen thinking. At the same time the language sign acts as the main object of the analysis.

Suggesting the ontological symbolic nature, P. A. Florensky determined a symbol as "the entity which is more than the symbol itself". He wrote that, "it could be understood as any reality the energy of which contained another one of both the highest value and reality's hierarchy" (Florensky, 1999, pp. 477-478). In other words, we communicate with reality by means of symbols and we touch something that has been cut off so far from our consciousness. We see the reality by an image, and we hear it by a name, with symbols "the openings made in our subjectivity". The symbols open "depths of our being by our spirit" to be born and realized. "A secret of the world is revealed by symbols in the authentic essence". According to Florensky, language, a word and a name are symbolic. A symbol's language is inseparable from our being, it is "aprioristic". The symbol's nature is antinomic: on the one hand, it is transcendental and, on the other, it is human. The danger of the antinomic nature is that subjectively created symbols can take away from reality, or merge with and smother it. Attempts to separate strict sense and a sensual cover from a symbol lead to the disappearance of spiritual content and the destruction of a symbol. A danger of this kind proceeds from rationalism and naturalism (Florensky, 2000, pp. 424-425).

\section{Results and Discussion}

The symbol as an element of cultural information is used in a speech and language code of national culture representatives. The generally accepted idea of the symbol comes to understanding it as some content which, in turn, serves as the expression for another culturally more valuable content (Lotman, 2004, p. 240). Archaism is one of a symbol's properties. Its main objective is to express the correlation between its invariant content and the modern cultural context. With the correlation, the information on objects, actions, phenomena, feelings, and properties is preserved and passes on from one generation to another in a condensed form. Joining in any syntagmatic row, the 
symbol saves semantic and structural originality.

According to Yu. M. Lotman, "the symbol never belongs to one synchronous cultural cutoff. It always crosses this cutoff down from the past to the future. Symbol's memory is more ancient, than memory of its nonsymbolic textual surrounding" (Lotman, 2004, p. 241). However, symbol as "the messenger of former cultural eras", not only appears in its invariable form, but also actively interacts with the modern cultural context, changes under its influence, affects it. The symbol belongs to a multivariate semantic space. Therefore, it is impossible to reveal all the symbol's content through the sphere of expression. In this regard, it is important to notice that:

\begin{abstract}
Semantic potentialities of the symbol are always wider than its semantic implementations: symbols' links with a semiotic surrounding by means of its expression plane don't exhaust all its semantic valences. That is why there is semantic reserve which can be used by the symbol to form unforeseen connections, changing entity and deforming a textual surrounding (Lotman, 2004, p. 242).
\end{abstract}

Thus, as an element of cultural information, a symbol has the following properties: a) archaism from a present-day perspective; b) semantic and structural originality; c) dynamism; d) wide semantic potential; e) variability. These features allow a symbol to save in a condensed form significant cultural information, to transfer it from the past to the future, to interact with a modern cultural context and influence it (Ganyushina, 2009, p. 43).

Signs can be called symbolical tools of knowledge. However, there is a substantial difference between a sign and a symbol in the language. N. V. Ivanov claims that if a sign is considered as the beginning of a symbol, then the symbol can be defined as "the most difficult result of semantic formation of a sign". A sign's semantic component is expressed in its meaning. On the contrary, the main thing in a symbol is a sense as logical category. The sign and the symbol interact continuously: "the symbol wants to be a sign, to develop in itself the properties of internal formalization in aspect of content and expression, and it can be considered as an experience of a symbol; the sign aspires to become a symbol, to find in itself the features of symbolization, and it can be understood as semantic experience of a sign, experience of its internal semantic development" (Ivanov, 2002, p. 51).

For a symbol to capture the most important aspect of meaningfulness, it is essential to be identical with the context. Ivanov emphasizes that the symbol in possession of its semantic uniqueness is always understood as some semantic continuation of a context. The sign, on the contrary, expresses some semantic restriction of a context and separates itself from it. Certainly, it should be taken into account that both symbol and sign have their own context: a sign has a so-called "proximate" context, its direct logical environment; a symbol possesses infinitely distant, general context.

Meaning can be considered as a sign's semantic basis while this is found in an image for the symbol. So, a sign can be considered as the result of a symbol's evolution while a symbol as an intermediate link of the movement from an image to a sign. Being one of the forms of symbolic world understanding, myth does not lose timeless fragments and continues to live in metaphors, idioms, proverbs and drawing ethnos' LWI.

As for image, it can be defined, according to M. M. Makovsky, as a form of mythogenic representation; it is a biological social product, the result of the interaction of a higher neurological activity and objective social conditions. The mythological image appears only in the word. For ancient people the word was not a sign, as we understand today, but it was a name. Language abstraction did not exist for them. Therefore, the word is determined as "a semiotic sign, a symbol, a semiotic formula of a mythopoetic image" (Makovsky, 1996, p. $20)$.

M. M. Makovsky notes: "Language is a peculiar cemetery of metaphors: the word which was once a metaphor can lose the obviously metaphorical properties over time, but then again be converted to metaphorical transformations which are quite often not similar with initial" (Makovsky, 1996, p. 16).

Thanks to metaphors' active nature, a special vision of the world is created. National and cultural sensitivities accumulated by nations during their historical development are imprinted in national languages. The metaphor is characteristic of human thinking and language.

Having analyzed some of the theoretical background, symbol can be considered as an intermediate position between linguistic sign and image, while the sign is a result of a symbol's evolution. Moreover, symbol can be defined as the fusion of archetypes, which are a myth's base. Hence, one more algorithm of LWI research follows - from myth to symbol to linguistic sign.

Our theoretical consequences have found confirmation in practical LWI research. The analysis of metaphorical constructions and idioms expressing the same idea in different languages (mainly Russian, English, German, and French) showed that in different languages the content of these ideas revealed by various images and symbols. This fact helps us to lift the veil on the understanding of a nation's mentality and obtain a real meeting of minds during communication between different nations' representatives.

Let us give some examples concerning the notions "wind" and "air". In the traditions of all nations these notions are an element that is necessary for life. In 
ancient times, the wind was equivalent with soul (cf.: English: wind, "German: Wind "wind", Ossetic: udd "soul") (Makovsky, 2005, p. 500). In idioms to recover one's wind, to catch / get one's second wind, the lexeme wind means "breath"; be down wind: "to feel bad"; be in the wind "to be slightly [a bit] drunk"- the position of the person relative to a wind explains their meaning. As for Russian, there is no identical idiom, while in French (Fr.) we have reprendre haleine and in German (Ger.) zu Atem kommen, where the lexemes 'der Atem' and 'haleine' breathing, respiration. As we know the lexemes with the meaning "breath" correlate with the meaning "fire". (Indo-European (I.E): "al-/*el- "to burn" but Lettish (Let.): elpēt "to breathe", Breton: alan " to breath", Old-English (O.-E.) oeðem "breath" , Germ.: Atem, Fr.: haleine ("breath”) (Makovsky, 2004, p.41). Moreover, wind also correlates with fire (compared with (I.E): "uendh- "make fire" ). In ancient times, fire was equated with wind and the soul (Makovsky, 2004, p. 582).

In the expression to blow hot and cold (i.e. to blow hot and cold wind), the elements of wind symbolize moral condition of the person: his constant doubts in decision-making, mood, relations; dual position. In this regard, the correlation of the meaning wind with the meaning "dark, blind" is interesting: Latin: aquilo "north", but Lithuanian: aklas "blind"; Greek: каıкís "a strong wind", but Latin: caecus "blind" (Makovsky, 1989, p. 51). The idiom be right before the wind with all the studding sails out means "be drunk" for the English. Neither German, nor French nor Russian has similar idioms.

Air, as one of four primary elements, symbolizes top and goes back to the meaning "burn", "be in movement"; "spirit, breath"; "to cut"; "to lift"; "to take". As the symbol of fast movement, air is represented in the form of a fast horse (cf. Russian: dialect. opь "horse") (Makovsky, 2005, p. 80).

On the assumption of the research results, the sense of the following expressions becomes clear: be on air "to broadcast", take air "to become known, become wellknown", to keep something in the air "to keep someone in a condition of uncertainty, uncertainty, expectation". The British call insignificant talk and chatter hot air. As the notion "air" correlates to "fire", be (get or go) up in the air means "lose one's temper"; "He's not a bad sort of fellow, used to get up in the air a bit quick, one time, but he's toned down now." Fish in the air means to "do useless things", to saw the air "to gesticulate a lot", "to swing one's arms".

By using classic physio-philosophical language of four elements: "earth", "water", "fire" and "air", it is possible to interpret the human body. As blood was equalized with the Universe, it was considered as the "home" of our soul and our life, as a birth symbol according to the beliefs of many peoples. Both English and Russian could not remain indifferent to this fact and expressed this idea in their idiomatic expressions, mostly to coincide with this concept, but there are also essential distinctions. The English use the idiom too rich for my blood (literally "it is too much for my blood", i.e. for my soul's home) having in mind "can't stand something" or 'that's too much, that's going too far".

«Red blood » symbolizes physical force and courage, while "bad blood" connotes hostility. According to ancient traditions of magic in Western Europe, blood was considered as the "special juice" impregnated with the personal aura of the donor, which is why all pacts with the devil were allegedly subscribed or fastened with blood. In addition, so-called "pure" and "dirty" blood were singled out. The coagulating blood from a wound that was not dangerous was considered pure. "Pure blood" always symbolized undisturbed vitality. According to medieval legends, pure blood had a salutary effect and could cure leprosy. On the other hand, "dirty" menstrual blood, because of a woman's contact with "mythical space, mythical forces", was considered to be charged with a negative force and associated with hostility. It attracted diseases and profaned the holy places. It explains English idiom breed ill blood: "to cause a quarrel between sb. and sb., to spread discord". Neither French, German (Mut; Tapferkeit) or Russian have equivalent constructions. Make somebody's blood creep (literally: make somebody's blood move slowly i.e. curdle from horror because it is the soul that lives there) means to "be horrified (by)". In German we can say, 'Sie wurde vom Grauen gepackt' where Grauen "terror, horror" can be correlated with the German word grau or "grey", known to be the transition between black and white. The closer grey gets to black, the more dramatic and mysterious it becomes. The closer it gets to silver or white, the more illuminating and lively it becomes. In the Christian religion, grey symbolizes mourning and repentance. It is the colour of ashes (Chevalier, 2004, p. 487). The idea of ruthless use of force is captured in "blood and iron", compare with the German, 'Blut und Eisen', Bismark's policy and the Russian огнём и мечом, literally "by fire and sword". Moreover, iron as a Mars' attribute (the war god) is associated with violence and colour of rust with blood. The English dichotomy blood and thunder as "bloody melodrama" goes back to understanding of thunder as the manifestation of divine wrath caused by the violation of a space order.

As Prof. M. M. Makovsky notes, "the blood concept can correlate to various sincere experiences: "to feel", "think", "understand", cf. Ossetic: tug "blood", but Irish tucu, New-Irish: tuigim "understand" (cf. Lithuanian: tikyoti "trust"); English: blood "blood", but English "brood" "to think, consider" (Makovsky, 2005, p. 500). This idea finds its expression in get something out of one's blood (i.e. to withdraw) having in mind "forget about something", "dismiss".

Red is known to be associated with blood, and bloody hands - with a crime, so, it is clear that to catch 
someone red handed means "catch/ take in the act". This symbolic content is traced in English, Russian and French expressions: in English to see red mist, its Russian equivalent смотреть сквозь красную пелену and in French, se facher tout rouge. But the symbolic association of red with danger is revealed in the English idioms: be in the red, out of the red, put in the red. (The same in French: compte en rouge "nominal account"). Moreover, bank clerks are known to score up debts and losses with red ink. The same symbolic meaning we can see in French expressions: être au rouge, être dans le rouge "be embarrassed; be in difficult situation". In Russian tradition, red is the symbol of beauty: therefore Red Square means "beautiful square" or красна девица (krasna devitsa) "a beautiful girl".

According to ancient biblical representations, the body of the person was compared to space (microcosm), with its foundation represented by a skeleton or bones. According to the beliefs of many peoples, the spirit of the living being remains in bones and preserving them may guarantee their possible revival. Thus, the following expressions become clearer: in English, to feel something in one's bones is to "sense something; suspect something" or "to be sure absolutely of something"; bred in the bone is "innate "; to have a bone in one's arm/leg means "to be tired"; to make no bones about something is to "have no hesitation in stating or dealing with (something), however unpleasant or awkward it is he makes no bones about his feelings towards the militants" (in interpretation: not to get up courage to undertake something). In French, ça vaut loos is "to be worthy"; l'avoir dans l'os is to "fail, suffer a major setback". In German, der Schreck ist ihm in die Knochen gefahren is "my heart was in my mouth", literally in German - 'in bones". Identity was also associated with a skeleton and bones. In cultures with shaman rituals skeletons are symbols of mental experience and disintegration of personality. Hence it is clear why skeleton in the closet means "a discreditable or embarrassing fact that someone wishes to keep secret", while in French, cadavre dans l'armoire literally "dead body in closet". But in German there is no an identical equivalent.

\section{Conclusion}

- Using the given algorithm of our study, the comparative method, and the method of multiple etymology introduced in linguistic science by V. N. Toporov, and having analyzed idioms and metaphorical constructions of concepts such as animals' images, plants, mechanisms, tools, clothes and others on 10 publication base sheets we can draw the following conclusions:In the history of studying of LWI phenomenon there are two approaches: cognitive and cultural-philosophical. Both are not so much conflicting as mutually reinforcing. That is why in LWI research it is necessary to consider basic ideas of both approaches.

- On the one hand, the ontological status of the LWI concept defines the correlation between language and consciousness: they have mutual correlation. On the other hand, this concept is considered as a so-called peculiar cultural matrix within which a person can think and act.

- The key idea is anthropocentricity and ethnocentricity of language. People's activity, their feelings and emotions, vast spaces are measured by a human relative to themselves, accepting everything in them, their inner world; and imaging themselves in the visual environment. LWI provides a model of such anthropocentrism for all ages. Any national language reflects not only knowledge about the world but also includes everything that isn't connected with objective reality, for example, mythological images, metaphors and idioms. By researching LWI the scientist should investigate the inner form of words considering it as the keeper of cultural traditions and meanings.

- The further we go beyond internal linguistics by examining a concept, the more obvious is its correlation with axiological and mythological ideas. Studying the meaning of mythological symbols in metaphors and idioms helps to uncover the hidden springs in the development of human thought and culture as reflected in language.

Cultural traditions and world-vision of any nation, undoubtedly, find their embodiment in language. To find the so-called "index understanding" which would help to define as far as differently the interlocutor perceives objective reality, it is necessary to consider the national way of thinking reflected in the lexical system of a language acting as a NLWI.

\section{References}

Apresyan, Yu. D. (1995). Obraz cheloveka po dannym jazyka: Popytka sistemnogo analiza [Image of the person according to language: Attempt of the system analysis]. Topics in the Study of Language, 1, 37- 67.

Arutyunova, N. D. (1976). Predlozhenie i ego smysl [Sentence and its sense]. Moscow, USSR: Nauka.

Basel Al-Sheikh, H. (2012). Sapir - Whorf hypothesis. Theory and Practice in Language Studies, 2(3), 642646.

Bulygina, T. V., Shmelyov, A. D. (2000). Peremeshhenie $\mathrm{v}$ prostranstve kak metafora jemocij [Movement in space as a metaphor of emotions]. In N. D. Aroutunova, I. B. Levontina (Eds.), Logicheskij analiz jazyka: Jazyki prostranstv (pp. 277 - 288). Moscow, Russia: Yazyki russkoj kul'tury.

Chevalier, J., \& Gheerbrant, A. (2004). Dictionnaire des 
symboles [Dictionary of symbols]. Paris, France: Robert Laffont / Jupiter.

Fefilov, A. I. (2004). Osnovy cognitologii [Fundamentals of cognitology]. Ulyanovsk, Russia: Ulyanovsk State University.

Florensky, P. A. (1999). U vodorazdelov myslej. Cherty konkretnoj metafiziki [At thought watershed. Features of specific metaphysics] (Vol. 1-3). Moscow, Russia: Mysl.

fon Humboldt, V. (2013). O razlichii stroenija chelovecheskih jazykov $i$ ego vlijanii na duhovnoe razvitie chelovechestva [About distinction of the human languages' structure and its influence on spiritual humanity development]. Moscow, Russia: URSS.

Ganyushina, M. A. (2009). Simvolika konstantnyh $i$ variativnyh chert $v$ jazykovoj kartine mira [Symbolics of constant and variant features in linguistic worldimage]. Moscow, Russia: TransArt.

Ivanov, N. V. (2002). Problemnye aspekty jazykovogo simvolizma (opyt teoreticheskogo rassmotrenija) [Problem aspects of language symbolism (experience of theoretical consideration)]. Minsk, Belarus: Propilei.

Khayrullina,R.H.(2008).Frazeologicheskaja kartinamira: Ot mirovidenija $k$ miroponimaniju [Phraseological world image: From a world perception to a worldview]. Moscow, Russia: Vagant.

Kornilov, O. A. (2003). Jazykovye kartiny mira kak otrazhenie nacional'nyh mentalitetov [Linguistic world-image as the reflection of national mentalities]. Moscow, Russia: CheRo.

Kubryakova, E. S. (1993). Vozvrashhajas' k opredeleniju znaka (pamjati Jakobsona) [Coming back to definition of a sign (in Jacobson's memory)]. Topics in the Study of Language, 4, 18 -28.

Kurbakova, S. N. (2013). Strukturoobrazujushhij jelement recheproizvodstva [Structural forming element of speech production]. In Sovremennye tendencii $v$ obrazovanii i nauke (Vol. 10, pp. 97-101). Tambov, Russia: Ucom.

Lakoff, G., Johnson, M. (1980). Metaphors we live by. Chicago, IL: The University of Chicago Press.

Leontyev, A. N. (1983). Dejatel'nost'. Soznanie. Lichnost'. Izbrannye psihologicheskie proizvedenija [Activity. Consciousness. Personality. Psychological selection] (Vol. 2, pp., 94-231). Moscow, USSR: Pedagogika.

Lotman, Yu. M. (2004). Semiosfera [Semiosphere]. St. Petersburg, Russia: Iskusstvo.

Makovskiy, M. M. (1989). Udivitel'nyj mir slov i znachenij: Illjuzii $i$ paradoksy $v$ leksike $i$ semantike [Amazing world of words and values: Illusions and paradoxes in lexicon and semantics]. Moscow, USSR: KomKniga.

Makovsky, M. M. (1996). Cravnitel'nyj slovar' mifologicheskoj simvoliki: obrazy mira i miry obrazov
[The comparative dictionary of mythological symbolics in Indo-European languages: Image of the world and worlds of images]. Moscow, Russia: Vlados.

Makovsky, M. M. (2004). Jetimologicheskij slovar' sovremennogo nemeckogo jazyka [Etymological dictionary of modern German]. Moscow, Russia: Azbukovnik.

Makovskiy, M. M.(2005). Bol'shoj jetimologicheskij slovar' sovremennogo anglijskogo jazyka [Big etymological dictionary of modern English]. Moscow, Russia: Azbukovnik.

Radchenko, O. A. (2002). Ponjatie jazykovoj kartiny mira $\mathrm{V}$ nemeckoj filosofii XX veka [Concept of linguistic world-image in the German philosophy of the XX century]. Topics in the Study of Language, 6, 140-158.

Radchenko,O.A.,Zakutkin,N.A.(2004).Dialekticheskaja kartina mira kak idiojetnicheskij fenomen [Dialectic world image as idioethnic phenomenon]. Topics in the Study of Language, 6, 25-47.

Shpet, G. G. (1927). Vvedenie v jetnicheskuju psihologiju [Introduction to ethnic psychology]. Moscow, USSR: Gosudarstvennaja Akademija Hudozhestvennyh Nauk.

Sidorov, E. V. (2011). Porjadok teksta [Text order]. Moscow, Russia: Russian State Social University.

Stepanov, Yu. S. (2001). Konstanty: Slovar' russkoj kul'tury [Constants: Dictionary of the Russian culture]. Moscow, Russia: Academic project.

Tarasov, E. F. (2004). Jazykovoe soznanie [Language consciousness]. Journal of Psycholinguistics, 2, 34-47.

Thalia, V.N.(1996). Russkaja frazeologija. Semanticheskij, pragmaticheskij $i$ lingvokul'turologicheskij aspekty [Semantic, pragmatical and linguocultural aspects]. Moscow, Russia: Languages of the Russian Culture.

Toporova,T.V.(1999). Drevnegermanskaja kosmogonija: Jazyk i mif [Old German cosmogony: Language and myth]. In Rossijskie issledovanija po mirovoj istorii $i$ kul'ture (Vol. 1). Lewiston, NY: The Edwin Mellen Press.

Vezhbitskaya, A. (1997). Jazyk. Kul'tura. Poznanie [Language. Culture. Knowledge]. Moscow, Russia: Russkie slovari.

Weisgerber, L. (1993). Rodnoj jazyk i formirovanie duha [Native language and spirit forming]. Moscow, Russia: Moscow State University.

Wittgenstein, L. (2003). Filosofskie issledovanija [Philosophical researches]. In Jazyki kak obraz mira (pp. 220-546). Moscow, Russia: AST.

Zaliznyak, A., Levontina, I., \& Shmelev, A. (2002). Kljuchevye idei russkoj jazykovoj kartiny mira [Key ideas of the Russian language world image]. Otechestvennye Zapiski, 3(4), 248-261.

Zhinkin, N. I. (1998). Jazyk. Rech'. Tvorchestvo [Language. Speech. Creativity]. Moscow, Russia: Labirint. 